\title{
Determinants of Information Asymmetries with Corporate Governance as a Moderating Variable in Manufacturing Companies Listed on the Indonesia Stock Exchange
}

\author{
Fenny Afrida ${ }^{1}$, Idhar Yahya ${ }^{1}$, Chandra Situmeang ${ }^{2}$ \\ ${ }^{1}$ Magister of Accounting, Faculty of Economics and Business, Sumatera Utara University, Medan, Indonesia \\ ${ }^{2}$ Department of Accounting, Faculty of Economics, Universitas Negeri Medan, Medan, Indonesia \\ Corresponding Author: Fenny Afrida
}

DOI: https://doi.org/10.52403/ijrr.20220131

\begin{abstract}
The purpose of this study was to examine and analyse the effect of XBRL, Voluntary Disclosure, Volatility, Audit Quality, Firm Size, and Stock Turnover on Information Asymmetry with Corporate Governance as a moderating variable in manufacturing companies listed on the Indonesian Stock Exchange. The population of this research are all manufacturing companies listed on the Indonesian Stock Exchange for the 2010-2020 periods as many as 125 companies. The sample of this study used purposive sampling method so that the selected sample amounted to 81 companies. The analytical technique used in this research is panel data regression analysis and moderating test. XBRL has a negative and insignificant effect on information asymmetry. However, in 2010-2014 where before the adoption of XBRL, XBRL had a positive and insignificant effect on information asymmetry. Voluntary disclosure has a positive and significant effect on information asymmetry. However, in 2010-2014 where before the adoption of XBRL, voluntary disclosure had no effect on information asymmetry. Volatility has no effect on information asymmetry. Audit quality has no effect on information asymmetry. Firm Size has no effect on information asymmetry. Stock turnover has no effect on information asymmetry. Variables good governance do not moderate the effect of XBRL, voluntary disclosure, volatility, audit quality, firm size, and stock turnover on information asymmetry.
\end{abstract}

Keywords: XBRL, Voluntary Disclosure, Volatility, Audit Quality, Firm Size, Stock Turnover, Information Asymmetry, Good Governance

\section{INTRODUCTION}

The rapid development of technology today makes it easier for people to obtain information. One of them is financial information. This information is needed quickly for the purpose of making financial decisions such as investments or loans given by interested parties to the company. During the current pandemic, the need for information through technological developments is very much needed.

The capital market is a place where financial instruments are traded, one of which is shares (Darmaji, 2012). The capital market also provides information related to financial performance and stock prices so that this information helps users of information make financial decisions that benefit them. The financial information can be directly used or inputted for analysis so that financial information can be used properly in making decisions. But the problem that often occurs in providing information is the lack of information submitted by the company to the public. The company did not thoroughly convey this information. Complete information can only be known by company agents, namely 
directors and managers, while parties outside the company obtain very minimal information (Manurung, 2013). As a result, information that is not obtained in detail affects the quality of financial reporting which results in the risk of making wrong decisions (Tohang \& Lan, 2017).

The difference in information between the agent and the principle causes information asymmetry. This is in accordance with what was stated in agency theory where there is a conflict of interest between the agency and the principal where the agency has important information in making decisions by the principal while the financial information submitted in the financial statements is not comprehensive in accordance with the information held by the agency. As a result, information asymmetry occurs where there is a difference in the information obtained by the agent and the principle due to the agent covering up the information submitted to the public. As a result of information asymmetry, principals make poor quality decisions. PT Garuda Indonesia (Persero) Tbk where the company recorded quite a sharp revenue in 2018 while in 2017 it recorded a loss. The financial statement engineering was carried out by recording income that should still be reported in the form of receivables amounting to USD239,940,000.

Information asymmetry arises when managers know more about internal information and the company's prospects in the future than shareholders and other stakeholders. Information asymmetry can cause an imbalance in the amount of information held between the agent and the principal. Information asymmetry will benefit one party who has more information (such as a manager) and harm the other party (Scott, 2015). The factors that influence the occurrence of information asymmetry are eXtensible Business Reporting Language (XBRL), voluntary disclosure of audit quality stock price volatility, firm size or company size, stock turnover or stock turnover volume. This study adds the effect of the moderating variable corporate governance $(\mathrm{CG})$ on the relationship between XBRL adoption and information asymmetry. This is also supported by the results of research from Tangngisalu (2020) which shows that the effect of information asymmetry on earnings management with good corporate governance as a moderating variable shows significant negative results. With the role of good corporate governance, the weak or reduced information asymmetry actions carried out by the management will reduce earnings management. This is due to good governance within the company. Companies with good CG are expected to have good quality financial reports, so that their financial statements are more transparent and information asymmetry for the company will decrease.

\section{LITERATURE REVIEW} Agency Theory

The theory that underlies the existence of information asymmetry in the business world is agency theory. Agency problems exist when there are conflicting goals between the principal and the agent (Liu, 2017). The agency relationship is a contract that occurs between the agent (manager) and the principal (shareholder). The basic principle of agency theory is that there is a working relationship between the parties who own the company in the form of equity participation called the principal and the manager of the company, namely the management and is referred to as the agent.

Therefore, the emergence of an agency relationship, namely the existence of an agency relationship where the principal gives authority to the agent to manage the company and it is hoped that all management policies can benefit the principal.

\section{Signaling Theory}

Financial information is needed by interested parties in making decisions. Therefore, inaccurate or late financial information will have an impact on investment decision making. One of the 
theories related to this financial information is signaling theory. According to this theory, the company provides encouragement related to financial information to external parties of the company. Previously, the existence of information asymmetry in the company caused the company's financial information to be known more by the company than external parties so that it had an impact on decision making. Therefore, the existence of this signal theory is expected to reduce information asymmetry so as to increase trust and reduce company uncertainty in the future.

Brigham and Houston (2010) state that signal theory is a behavior of company management that provides instructions for investors about how management views the company's prospects where managers of an entity have voluntary incentives to report information to the capital market even though there are no provisions requiring.

\section{Information Asymmetry}

Corporate disclosure is a mandatory voluntary activity to provide information about corporate performance and governance to outside investors and is one of the fundamental elements for capital market efficiency (Shaw, 2003). Incomplete company disclosures will be closely related to the emergence of information asymmetry problems that will have an impact on efficiency in the capital market. Information asymmetry occurs when one party in a transaction has more or better information than the other party (Biswas, 2004).

$$
\text { Information asymmetry is a }
$$

condition in which managers have access to information on company prospects that is not owned by outsiders. Scott (2015) states that information asymmetry can be interpreted as one type of participant in the sense that sellers in the market know about the assets being traded while other types of participants, namely buyers, do not know it, this situation causes information asymmetry.

The previous studies as discussed above generally focused on the quality of information in terms of the quantity of content. XBRL as a technology used for financial reporting does not increase the quantity of information presented but rather increases the quality of the information presented (Debreceny et al. 2010). Presentation of financial information in XBRL format allows better access to information and automatic and more accurate processing of financial data. Debreceny et al (2010) argue that the XBRL extension when used properly can add value to stock market participants. With these benefits, XBRL is seen as a reporting format with better disclosure quality than other formats.

\section{eXtensible Business Reporting Language (XBRL)}

XBRL is the language for electronic communication of business and financial data around the world (Cormier, 2018). XBRL is a product of XBRL International, a non-profit consortium (www.xbrl.org). Started in 1998 by Charles Hoffman, XBRL is supported by many jurisdictions around the world and used by more than 100 regulators. The recognition of XBRL tags enables the automatic processing of business information by computers into software, thereby bypassing tedious and expensive manual processes (Alles, \& Piechoki, 2012). In addition, XBRL can increase the speed of reporting financial data and reduce the risk of error by checking information automatically (Liu, Luo, Sia, O'Farrell, \& Teo, 2014).

XBRL can support financial data and non-financial data, so this is what distinguishes XBRL from traditional financial documents (Debreceny et al. 2005). Mahardika (2018) states that XBRL is an XML-based standard business reporting language that was developed to facilitate electronic communication of financial data and business data. The use of XBRL can increase efficiency, reliability, and accuracy in financial reporting (Yoon et al, 2011). 
Chen, Harris, $\mathrm{Li}$ and $\mathrm{Wu}(2015)$ find that the adoption of XBRL leads to a significant reduction in the cost of equity capital due to a decrease in information processing costs. Yoon et al. (2011), Kim and Lim (2013) have documented the impact of XBRL on information asymmetry. Generally, the use of XBRL is associated with an increased level of transparency in financial reporting. If the level of financial disclosure is increased by adopting XBRL, information asymmetry is expected to decrease, which can lead to a decrease in the cost of equity capital and an increase in the market value of the company's shares (Yoon et al, 2011).

\section{Voluntary Disclosure}

Voluntary disclosure is the disclosure of information by the company voluntarily, without being forced by regulations. Patelli and Prencipe (2007), and Leung and Horwitz (2004) examined the relationship between board independence and voluntary disclosure of information. They estimate that independent directors have greater incentives than internal directors to encourage companies to disclose more information to investors. Consistent with this prediction, they found a positive relationship between the proportion of independent directors and the level of voluntary disclosure. In contrast, Eng and Mak (2003) investigated firms listed on the Singapore Stock Exchange and found that an increase in the number of external directors (blockholders) reduces (unrelated to) the level of corporate voluntary disclosure.

Khoshbakht and Mohammadzadeh (2011) and Soheilyfar, Tamimi, Ahmadi, and Takhtaei (2014)) find that the proportion of independent directors on the board and institutional ownership are positively related to the level of voluntary disclosure. However, Al-Shammari and AlSultan (2010) found no relationship between board independence and the level of voluntary disclosure for companies listed on the Kuwait Stock Exchange. Studies document a negative relationship between CEO duality leadership and voluntary disclosure (Lin et al., 2014). These results indicate that the separation of CEO and board chairman increases the effectiveness of board monitoring and improves the quality of information disclosure. However, Soheilyfar et al. (2014) reported a significant positive relationship between CEO duality and voluntary disclosure.

\section{Volatility}

The state of rising or falling of stock prices within a certain period of time is also called volatility. Santioso and Angesti (2019) argue that volatility is a condition where stock prices deviate (up/down) in the index from the average. Market volatility occurs due to the entry of new information into the market or exchange. As a result, market participants reassess the assets they trade. That way, if the investment manager or investor misunderstands the volatility of the stock, it will have an impact on the return and risk that will be received from the stock investment made. Stock price volatility (Hussainey et al., 2011) is a measure in determining risk in investment and can show the level of change in stock prices over a certain period of time.

Research conducted by Frino et al (2015) and Batchelor et al (2014) shows that volatility has a positive effect on information asymmetry, where high volatility indicates the uncertainty of information obtained by interested parties in making decisions, thereby increasing information asymmetry. However, research conducted by Cahyani, et al (2019) shows that volatility has a positive insignificant effect on the existence of information asymmetry, one must set high volatility at these times.

\section{Audit Quality}

The importance of auditors in a company to ensure that the financial information submitted is valid or not. Tandiontong (2016) argues that audit quality is related to the possibility of an 
Fenny Afrida et.al. Determinants of information asymmetries with corporate governance as a moderating variable in manufacturing companies listed on the Indonesia stock exchange.

auditor in searching for, finding, and reporting fraud or errors in the company's accounting system. Indicators that determine audit quality are the assignment of personnel by KAP to carry out agreements, consultations, supervision, inquiry, professional development, promotions and inspections (Sari, 2018). In addition, to achieve a good audit quality, an auditor must have the ability to use technology, perform audit procedures correctly, and conduct audits by taking the right sample. Choi \& Gary (2010) stated that the size of the KAP will affect the quality of the audit where the larger the size of the KAP indicates a good reputation in producing quality audits. The use of large public accounting firms also affects public confidence in the quality of financial information presented in financial statements. Meanwhile, according to Sari (2018), there are several indicators that determine an auditor to produce a quality opinion.

\section{Firm Size}

Firm size is a variable that is widely used to explain variations in disclosures made by companies in the company's financial statements. This is associated with agency theory where large companies that have greater agency costs will disclose wider information to reduce agency costs. Based on research conducted by Yoon et al (2011) the application of XBRL in large companies can reduce the level of information asymmetry more significantly than small and medium-sized companies. Large companies tend to have more frequent trading activities and receive attention from the media and analysts, so that the information asymmetry of large companies is lower than that of small companies. Research conducted by Cahyani et al (2019), Rahman (2016) states that firm size has a negative and insignificant relationship to information asymmetry. This is different from the research conducted by Mahardika (2018) which states that firm size has a negative and significant effect on information asymmetry.

\section{Stock Turnover}

Stock turnover is the ratio of stock turnover. Stock turnover can be calculated by dividing the total number of shares traded during a period by the average number of shares outstanding for that period, then the daily turnover ratio is averaged for one year (Abad, 2017). This ratio reflects the level of stock trading activity where how often the stock is traded. Mahardika (2018) argues that stocks that are often traded have high liquidity so that they will attract investors and will increase the tendency that important information can be reflected in the stock price. In Tzu-Yi's research (2016) the stock turnover ratio was used as a proxy for information asymmetry and obtained significant negative results on information asymmetry. However, in contrast to the results of research conducted by Afridah and Heri Yanto (2015), Mahardika (2018) which found a positive and insignificant effect between stock turnover and information asymmetry.

\section{Corporate Governance}

Corporate governance is a structural system of institutional policies whose principals are related to the interests of shareholders, equal treatment of shareholders, the role of all interested parties (stakeholders), transparency and clarity. Large-scale companies have paid attention to the importance of corporate governance. Cormier et al (2018) argue that good governance can improve earnings quality, and poor governance leads to poor earnings quality. This is in accordance with the research of Althanasakou and Olsson (2012) which separates the innate and discretionary income components of quality. Their results show that higher discretionary income is associated with better governance. On the other hand, companies with good governance will tend to produce more and more information frequently so that the 
Fenny Afrida et.al. Determinants of information asymmetries with corporate governance as a moderating variable in manufacturing companies listed on the Indonesia stock exchange.

quantity of information produced increases (Beeke et al. 2012).

\section{MATERIALS \& METHODS}

The design of this research is explanatory research, namely research design to analyze the relationship between variables to test a theory or hypothesis from existing research. In this research, the method used is documentation. The data used is secondary data, namely primary data that has been further processed, for example in the form of numbers, tables, graphs, diagrams and so on so that it is more informative if used by outsiders (Umar, 2003). The secondary data in this study comes from the financial statements of manufacturing companies listed on the Indonesia Stock Exchange for the period 2010-2020 which were downloaded from the Indonesia Stock Exchange website, namely www.idx.co.id. The dependent variable in this study is Information Asymmetry. Measurement of the level of information asymmetry in the capital market cannot be observed directly. This study measures the level of information asymmetry by using the ratio analysis of the bid-ask spread. The use of bid-ask spread as a proxy for information asymmetry is in line with research conducted by Yoon et al. (2011), F Tzu et al. (2016), Chong et al (2017).

XBRL is a dummy variable for XBRL adoption, which is worth 1 if it is in the period after XBRL adoption (already adopted) and will be worth 0 if it is in the period before adoption (not yet adopted). This is because this study aims to examine the effect of XBRL adoption on information asymmetry so that this variable is treated as a dummy variable. The voluntary disclosure is measured by the voluntary disclosure index list issued through Bapepam regulation No: KEP-347/BL/2012. The calculation is measured by dividing the total voluntary disclosure submitted in the financial statements divided by the total voluntary disclosure items that should be.
Stock volatility indicates the level of risk of stock uncertainty. To obtain the annual standard deviation, the daily standard deviation is annualized by multiplying by the root 250, assuming that there are 250 trading days in a year. If the information asymmetry is low enough and the market is efficient enough, then stock price volatility tends to be low. Wang et al (2014) argue that if there is an increase in information asymmetry, it will cause stock price volatility to increase due to a fairly strong adverse selection among investors in the capital market.

$$
\begin{aligned}
& \sigma=\sqrt{\frac{1}{N} \sum_{1}^{N}\left(R_{t}-\bar{R}\right)^{2}} \\
& \sigma \text { annualized }=\sigma \sqrt{250}
\end{aligned}
$$

The measurement of audit quality uses a dummy variable where if it is checked by a KAP affiliated with the big four, it is given a value of 1 while if it is not affiliated with the big four it will be given a value of 0 .

Large companies tend to have more frequent trading activities and receive attention from the media and analysts, so that the information asymmetry of large companies is lower than that of small companies. Yoon et al (2011) company size is calculated using stock market capitalization ie, stock price $\mathrm{x}$ number of shares outstanding in that period.

Stock turnover shows the number of stock turnover in buying and selling activities. In the Tzu-Yi (2016) study, the stock turnover ratio was used as a proxy for information asymmetry and obtained significant negative results on information asymmetry. Stock turnover can be calculated by dividing the total number of shares traded during the period by the average number of shares outstanding for the period. The daily turnover ratio is then averaged for one year. This ratio reflects the level of stock trading activity where how often the stock is traded.

The corporate governance (CG) variable is the moderating variable in this 
Fenny Afrida et.al. Determinants of information asymmetries with corporate governance as a moderating variable in manufacturing companies listed on the Indonesia stock exchange.

study, which is moderating the effect of XBRL adoption on information asymmetry. In a previous study conducted by Verrecchia (2001), there was a negative relationship between the effectiveness of the supervisory board and the company's information asymmetry. The CG score used consists of several components, namely: (1) board structure, (2) compensation policy, (3) board functions, (4) shareholder rights. To measure the $\mathrm{CG}$ variable, the $\mathrm{CG}$ score obtained from the Data stream is used. The calculation of the CG Score includes 4 aspects, namely the structure of the board, compensation/incentive policies, board functions, and shareholder rights. The scores for each of these aspects are combined to obtain an overall score with a range of $0 \%$ (low CG application) to $100 \%$ (high CG application). XBRL, CG shows the moderating variable obtained by multiplying the XBRL variable with CG.

The population in this study are manufacturing companies listed on the Indonesia Stock Exchange in a row in the 2010-2020 period, totaling 81 companies. The sampling technique in this study used a purposive sampling technique. The number of years of observation used in this study was 11 consecutive years so that the number of observations in this study was $11 \times 81$ samples, so as many as 891 observation samples were obtained.

The data analysis methods in this study are descriptive statistics, multiple regression analysis (Multiple Regression Analysis) and the Moderate Regression Analysis (MRA) test for moderating variables. These descriptive statistics are used to provide an overview for the profile of the sample. This study uses descriptive statistics consisting of the average value, standard deviation, minimum and maximum. The classical assumption test used in this study includes the normality test, multicollinearity test, autocorrelation test, and heteroscedasticity test.

\section{RESULT}

Descriptive statistical analysis is used to determine the description of a data seen from the maximum value, minimum value, average value (mean), and standard deviation value.

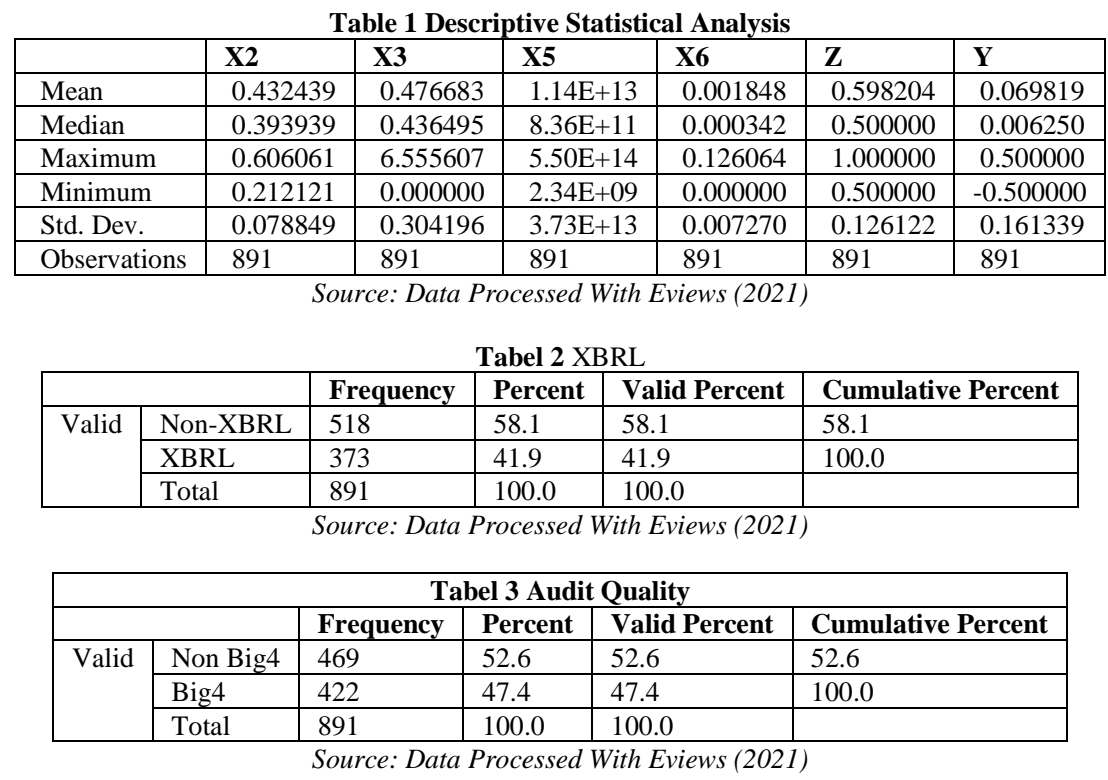

Based on tables 2 and 3, it is known that the percentage that does not use XBRL is $58.1 \%$, while those who use XBRL are $41.9 \%$. It is known that the percentage of audit quality that is not affiliated with
Bigfour is $52.6 \%$, while those with Bigfour affiliates are $47.4 \%$.

\section{Hypothesis Testing Period 2010-2014}

In testing the hypothesis, the analysis of the coefficient of determination 
Fenny Afrida et.al. Determinants of information asymmetries with corporate governance as a moderating variable in manufacturing companies listed on the Indonesia stock exchange.

will be carried out, simultaneous effect testing ( $\mathrm{F}$ test), and partial effect testing ( $\mathrm{t}$ test). Statistical values of the coefficient of determination, $\mathrm{F}$ test, and $\mathrm{t}$ test are presented in Table 4

Table 4. Statistical value of $t$ test (2010-2014)

\begin{tabular}{|l|l|l|l|l|}
\hline Variable & Coefficient & Std. Error & t-Statistic & Prob. \\
\hline X1 & 0.340447 & 0.365831 & 0.930612 & 0.3526 \\
\hline X2 & 0.773523 & 0.526182 & 1.470068 & 0.1423 \\
\hline X3 & 0.372910 & 0.111882 & 3.333074 & 0.0009 \\
\hline X4 & -0.000535 & 0.089697 & -0.005965 & 0.9952 \\
\hline X5 & -0.005444 & 0.019184 & -0.283762 & 0.7767 \\
\hline X6 & 2.824151 & 3.795503 & 0.744078 & 0.4573 \\
\hline C & -0.389085 & 0.520043 & -0.748179 & 0.4548 \\
\hline \multicolumn{7}{|c|}{ Source: Data Processed With Eviews (2021) } \\
\hline
\end{tabular}

Based on Table 4, the results obtained XBRL has a positive effect on information asymmetry, with a coefficient value of 0.340 , but it is not significant with the value of Prob. $0.3526>0.05$. Voluntary disclosure has a positive effect on information asymmetry, with a coefficient value of 0.7735 , but not significant with a Prob. value. $0.1423>0.05$. Volatility has a positive effect on information asymmetry, with a coefficient value of 0.3729 and significant with a Prob. value. 0.0009 < 0.05 . Audit quality has a negative effect on information asymmetry, with a coefficient value of -0.0005 , but not significant with the value of Prob. $0.9952>0.05$. Firm Size has a negative effect on information asymmetry, with a coefficient value of -0.0054 , but not significant with the Prob value. $0.7767>$ 0.05 .

Stock turnover has a positive effect on information asymmetry, with a coefficient value of 2.8241 , but not significant with the value of Prob. $0.4573>$ 0.05 .

\section{Moderated Regression Analysis (MRA) Test Period 2010-2014}

Furthermore, a moderating test was conducted, which was to test whether corporate governance was significant as a moderator of the relationship between XBRL, voluntary disclosure, volatility, audit quality, firm size, stock turnover on information asymmetry. Table 5 presents the results of the moderation test.
Table 5 MRA Test Period 2010-2014

\begin{tabular}{|l|l|l|l|l|}
\multicolumn{7}{c}{ Table 5 MRA Test Period 2010-2014 } \\
\hline Variable & Coefficient & Std. Error & t-Statistic & Prob. \\
\hline X1 & 1.736188 & 2.713780 & 0.639767 & 0.5227 \\
\hline X3 & 1.259184 & 2.726510 & 0.461830 & 0.6445 \\
\hline X4 & 0.432710 & 0.828116 & 0.522523 & 0.6016 \\
\hline X5 & 0.131110 & 0.467364 & 0.280530 & 0.7792 \\
\hline X6 & -0.155563 & 0.099720 & -1.559993 & 0.1196 \\
\hline X1Z & -3.071599 & 40.93196 & -0.075042 & 0.9402 \\
\hline X2Z & -0.904717 & 4.012278 & -0.225487 & $\mathbf{0 . 8 2 1 7}$ \\
\hline X3Z & -0.545197 & 4.226956 & -0.128981 & $\mathbf{0 . 8 9 7 4}$ \\
\hline X4Z & -0.128353 & 1.171065 & -0.109604 & $\mathbf{0 . 9 1 2 8}$ \\
\hline X5Z & -0.139298 & 0.720522 & -0.193329 & $\mathbf{0 . 8 4 6 8}$ \\
\hline X6Z & 0.237408 & 0.153534 & 1.546289 & $\mathbf{0 . 1 2 2 8}$ \\
\hline Z & 8.792227 & 55.84563 & 0.157438 & $\mathbf{0 . 8 7 5 0}$ \\
\hline C & -5.588192 & 4.142906 & -1.348858 & 0.1782 \\
\hline
\end{tabular}

Based on the results of the moderation test in Table 5, it can be concluded corporate governance is not significant as a moderator of the relationship between XBRL and information asymmetry, with the value of Prob. $0.8217>0.05$. Corporate governance is not significant as a moderator of the relationship between voluntary disclosure and information asymmetry, with the value of Prob. 0.8974 > 0.05. Corporate governance is not significant as a moderator of the relationship between volatility and information asymmetry, with the value of Prob. 0.9128 > 0.05. Corporate governance is not significant as a moderator of the relationship between audit quality and information asymmetry, with the value of Prob. $0.8468>$ 0.05. Corporate governance is not significant as a moderator of the relationship between firm size and information asymmetry, with the value of Prob. $0.1228>$ 0.05. Corporate governance is not significant as a moderator of the relationship between stock turnover and information asymmetry, with the value of Prob. $0.8750>$ 0.05 .

\section{Hypothesis Testing Period 2015-2020}

In testing the hypothesis, the analysis of the coefficient of determination will be carried out, simultaneous effect testing ( $\mathrm{F}$ test), and partial effect testing ( $\mathrm{t}$ test). Statistical values of the coefficient of determination, $\mathrm{F}$ test, and $\mathrm{t}$ test are presented in Table 6: 
Fenny Afrida et.al. Determinants of information asymmetries with corporate governance as a moderating variable in manufacturing companies listed on the Indonesia stock exchange.

Table 6 Statistical values of the Coefficient of Determination, F-Test, and t-Test (2015-2020)

\begin{tabular}{|c|c|c|c|c|}
\hline Variable & Coefficient & $\begin{array}{l}\text { Std. } \\
\text { Error }\end{array}$ & t-Statistic & Prob. \\
\hline $\mathrm{X} 1$ & -0.011875 & 0.087955 & -0.135015 & 0.8927 \\
\hline $\mathrm{X} 2$ & 1.151524 & 0.461874 & 2.493154 & 0.0130 \\
\hline $\mathrm{X} 3$ & 0.088514 & 0.092150 & 0.960538 & 0.3373 \\
\hline $\mathrm{X} 4$ & 0.143621 & 0.084718 & 1.695272 & 0.0907 \\
\hline $\mathrm{X} 5$ & -0.030741 & 0.019052 & -1.613540 & 0.1073 \\
\hline $\mathrm{X} 6$ & 17.99282 & 4.917458 & 3.658968 & 0.0003 \\
\hline $\mathrm{C}$ & 0.264622 & 0.526151 & 0.502940 & 0.6152 \\
\hline R-squared & 0.060671 & \multicolumn{2}{|c|}{ Mean dependent var } & 0.028561 \\
\hline $\begin{array}{l}\text { Adjusted R- } \\
\text { squared }\end{array}$ & 0.048905 & \multicolumn{2}{|c|}{ S.D. dependent var } & 0.832520 \\
\hline $\begin{array}{l}\text { S.E. of } \\
\text { regression }\end{array}$ & 0.811908 & \multicolumn{2}{|c|}{ Akaike info criterion } & 2.435440 \\
\hline $\begin{array}{l}\text { Sum } \\
\text { squared } \\
\text { resid }\end{array}$ & 315.7543 & \multicolumn{2}{|c|}{ Schwarz criterion } & 2.495735 \\
\hline $\begin{array}{l}\text { Log } \\
\text { likelihood }\end{array}$ & -584.8118 & \multicolumn{2}{|c|}{ Hannan-Quinn criter. } & 2.459128 \\
\hline F-statistic & 5.156383 & \multicolumn{2}{|c|}{ Durbin-Watson stat } & 2.077033 \\
\hline $\begin{array}{l}\text { Prob } \\
\text { (F-statistic) }\end{array}$ & 0.000038 & & & \\
\hline
\end{tabular}

\section{Analysis of the Coefficient of}

\section{Determination for the 2015-2020 Period}

Based on Table 6, it is known that the coefficient of determination (R-squared) is . This value can be interpreted as XBRL, voluntary disclosure, volatility, audit quality, size, stock turnover simultaneously or jointly affect information asymmetry by $6 \%$, the remaining $94 \%$ is influenced by other factors.

\section{Simultaneous Effect Significance Test (Test F) Period 2015-2020}

The test aims to test the effect of the independent variables together or simultaneously on the dependent variable. Based on Table 6, it is known the value of Prob. (F-statistics), which is 0.000038 0.05, it can be concluded that all independent variables, namely XBRL, voluntary disclosure, volatility, audit quality, firm size, stock turnover simultaneously, have a significant effect on information asymmetry variables.

Based on Table 6, the results obtained are: XBRL has a negative effect on information asymmetry with a coefficient value of -0.0118 , but it is not significant with the value of Prob. $0.8927>0.05$. Voluntary disclosure has a positive effect on information asymmetry with a coefficient value of 1.1515 , and is significant with a
Prob value. $0.0130<0.05$. Volatility has a positive effect on information asymmetry with a coefficient value of 0.0885 , but it is not significant with the value of Prob. $0.3373>0.05$. Audit quality has a positive effect on information asymmetry with a coefficient value of 0.1436 , but it is not significant with the value of Prob. $0.0907>$ 0.05 . Firm size has a negative effect on information asymmetry with a coefficient value of -0.0307 , but it is not significant with the value of Prob. $0.1073>0.05$. Stock turnover has a positive effect on information asymmetry with a coefficient value of 17.992, and is significant with a Prob value. $0.0003<0.05$. Furthermore, a moderating test was conducted, which was to test whether corporate governance was significant as a moderator of the relationship between XBRL, voluntary disclosure, volatility, audit quality, firm size, stock turnover on information asymmetry.

\begin{tabular}{|c|c|c|c|c|}
\hline Variable & Coefficient & Std. Error & t-Statistic & Prob. \\
\hline $\mathrm{X} 1$ & 0.297354 & 0.459423 & 0.647234 & 0.5178 \\
\hline $\mathrm{X} 2$ & 5.070729 & 2.483257 & 2.041967 & 0.0417 \\
\hline $\mathrm{X} 3$ & -0.868863 & 0.719932 & -1.206869 & 0.2281 \\
\hline $\mathrm{X} 4$ & 0.271655 & 0.435517 & 0.623753 & 0.5331 \\
\hline $\mathrm{X} 5$ & -0.077176 & 0.095018 & -0.812224 & 0.4171 \\
\hline $\mathrm{X} 6$ & 67.56181 & 39.84718 & 1.695523 & 0.0906 \\
\hline $\mathrm{Z}$ & 0.510214 & 4.646877 & 0.109797 & 0.9126 \\
\hline $\mathrm{X} 1 \mathrm{Z}$ & -0.559584 & 0.797034 & -0.702084 & 0.4830 \\
\hline $\mathrm{X} 2 \mathrm{Z}$ & -6.936999 & 4.363856 & -1.589649 & 0.1126 \\
\hline X3Z & 1.855575 & 1.355058 & 1.369370 & 0.1715 \\
\hline $\mathrm{X} 4 \mathrm{Z}$ & -0.187522 & 0.736649 & -0.254561 & 0.7992 \\
\hline $\mathrm{X} 5 \mathrm{Z}$ & 0.085191 & 0.159687 & 0.533486 & 0.5939 \\
\hline X6Z & -96.80980 & 75.47465 & -1.282680 & 0.2002 \\
\hline $\mathrm{C}$ & -0.123064 & 2.716901 & -0.045296 & 0.9639 \\
\hline
\end{tabular}

Based on the results of the moderation test in Table 7 , it can be concluded: Corporate governance is not significant as a moderator of the relationship between XBRL and information asymmetry, with the value of Prob. $0.4830>0.05$. Corporate governance is not significant as a moderator of the relationship between voluntary disclosure and information asymmetry, with the value of Prob. 0.1126 > 0.05. Corporate governance is not significant as a moderator of the relationship between volatility and information asymmetry, with the value of Prob. $0.1715>$ 
Fenny Afrida et.al. Determinants of information asymmetries with corporate governance as a moderating variable in manufacturing companies listed on the Indonesia stock exchange.

0.05. Corporate governance is not significant as a moderator of the relationship between audit quality and information asymmetry, with the value of Prob. $0.7992>$ 0.05. Corporate governance is not significant as a moderator of the relationship between firm size and information asymmetry, with the value of Prob. $0.5939>$ 0.05. Corporate governance is not significant as a moderator of the relationship between stock turnover and information asymmetry, with the value of Prob. $0.202>$ 0.05 .

\section{DISCUSSION}

The results of this study indicate that prior to the adoption of the eXtensible Business Reporting Language (XBRL), 2010-2014, it had a positive effect on information asymmetry. Meanwhile, the time after the adoption of XBRL in 20152020 had a negative effect. With the results of the analysis conducted on manufacturing companies in 2010-2020 which are listed on companies on the Indonesia Stock Exchange. The results obtained in this study found that XBRL had no significant effect on information asymmetry. This indicates that $\mathrm{H} 1$ in this study was rejected. This is in line with research conducted by Zamroni and Aryani (2018) which states that the implications of XBRL in Indonesia do not have significant implications in the Indonesian capital market. Septianingrum (2020) states that the application of XBRL has no effect on information asymmetry in manufacturing companies for the 2016-2018 period. Japutri's research (2019) also got the same results where XBRL had a negative and insignificant effect on the companies studied using the banking sector in 20162018.

The results of this study indicate that voluntary disclosure in 2010-2014 has a positive and insignificant effect on information asymmetry. Meanwhile, the time after the adoption of XBRL in 20152020 had a positive and significant effect on information asymmetry. With the results of an analysis conducted on manufacturing companies in 2010-2020 listed on companies on the Indonesia Stock Exchange, it was found that voluntary disclosure, which is measured by using the total voluntary disclosure index of the company divided by the number of voluntary disclosure indexes, has a positive and significant coefficient on information asymmetry. These results indicate that the higher a company is in providing voluntary disclosure, the higher the level of information asymmetry in the company. Based on signaling theory in which managers give signals to interested parties related to voluntary disclosure, it shows that before the use of XBRL there was no significant effect between voluntary disclosure and information asymmetry. But after the use of XBRL where voluntary disclosure affects the increase in information asymmetry because managers convey information so that interested parties are interested in investing in the company. This is also supported by agency theory, where the agent's interest is to obtain profits in the form of incentives so that the delivery of information when using XBRL is expected to attract investors to invest in the company. This is contrary to research conducted by Indriani (2013), and Damayanti (2016) which states that voluntary disclosure has a negative and significant effect on information asymmetry.

The results of this study indicate that volatility has a positive and insignificant effect on information asymmetry. With the results of the analysis conducted on manufacturing companies in 2010-2020 listed on companies on the Indonesia Stock Exchange, it was found that volatility as measured by the ratio of the highest stock price at time $t$ divided by the lowest stock price at time $t$ has a positive coefficient and is not significant to asymmetry. information. Market volatility occurs due to the entry of new information into the market or exchange. As a result, market participants reassess the assets they trade. That way, if the investment manager or investor 
misunderstands the volatility of the stock, it will have an impact on the return and risk that will be received from the stock investment made. Stock price volatility according to (Hussainey et al., 2011) is a measure in determining risk in investment and can show the level of change in stock prices over a certain period of time. Yoon et al. (2011) suggests that the relationship between stock prices and spreads is relatively inconclusive because markets with high information asymmetry pose challenges for investors to accurately assess company performance.

The results of this study indicate that audit quality in 2010-2014 has a negative and insignificant effect on information asymmetry. Meanwhile, the time after the adoption of XBRL in 2015-2020 had a positive and insignificant effect on information asymmetry. With the results of an analysis conducted on manufacturing companies in 2010-2020 listed on companies on the Indonesia Stock Exchange, it was found that audit quality, as measured by the dummy variable, had a positive and insignificant coefficient on information asymmetry.

This research is in line with research conducted by Oktoriza and Surjawati (2019) where the results of the study show that audit quality has no effect on information asymmetry. Where the sample companies in this study were audited by the big four affiliated KAPs at $47.4 \%$ and those not audited by the big four affiliated KAPs were $58.1 \%$.

The results of this study indicate that firm size has a negative and insignificant effect on information asymmetry. With the results of an analysis conducted on manufacturing companies in 2010-2020 listed on companies on the Indonesia Stock Exchange, it was found that firm size as measured by stock price capitalization has a negative and insignificant coefficient on information asymmetry. Information from large companies is likely to be easier to provide than small companies because of high trading activity and getting more attention from the media and investment analysts, thereby reducing the level of information asymmetry. This result is in line with the results of research conducted by Cahyani (2019) which states that firm size has a negative but not significant effect on information asymmetry in industrial and chemical companies in Indonesia.

The results of this study indicate that stock turnover has a positive and insignificant effect on information asymmetry. With the results of an analysis conducted on manufacturing companies in 2010-2020 listed on companies on the Indonesia Stock Exchange, it was found that stock turnover as measured by the ratio of stock trading volume divided by the number of shares outstanding each day was then averaged for one year. This means that shares that are often traded have high liquidity, the higher the level of risk of information asymmetry in the company. This is in line with Mahardika's research (2018) which states that stock turnover has no effect on information asymmetry. Based on agency theory, where information submitted by agents is one of them through financial reports, it is expected to increase stock prices. However, the use of XBRL where the principal obtains information in a timely manner avoids errors in obtaining information. Principals will find it easier to obtain correct information so they will be more careful in making decisions where stock prices are not information related to company performance. Based on the results of the Moderating Regression Analysis (MRA) test before the adoption of XBRL in 2010-2014 and after the adoption of XBRL in 2015-2020, it was found that the good governance variable did not moderate the relationship between XBRL's influence on information asymmetry. This proves that the existence of the role of $\mathrm{CG}$ is not able to strengthen the relationship between XBRL and information asymmetry.

The same results were also obtained by Apriani (2018) and Utomo (2020) who concluded that $\mathrm{CG}$ was able to suppress the level of information asymmetry but had no 
significant effect on moderating the relationship of variables to information asymmetry. However, a different conclusion from the research was obtained by Mahardika and Siti (2018) who found that there was a positive relationship from the role of $\mathrm{CG}$ to strengthen XBRL in suppressing the level of information asymmetry.

In line with the previous, related to signal theory, it is stated that the sender as the sender of information must know how to send or communicate information to the receiver, namely the party receiving and interpreting the information. Implementation of XBRL has no impact on trading behaviour. Even though the company has implemented Corporate Governance to strengthen the influence of XBRRL in suppressing information asymmetry, it is still not able to provide results that are in accordance with the existing theory because investors prefer not to apply XBRL technology because they do not get significant benefits from reading the information in the report.

According to Scott (2015), agency theory explains that there is a relationship between the agent and the principle that can cause information asymmetry due to the imbalance of information obtained. In the hypothesis, it is hoped that the application of CG can strengthen the effect of XBRL in reducing the level of information asymmetry in agency theory. However, the implementation of CG in Indonesia has not been able to be implemented effectively. The existence of CG should play a role in providing supervision and providing output in the form of confidence to investors that what they invest is safe. However, in its implementation, GCG is only a form of formality in an effort to comply with existing regulations, in contrast to the purpose of its implementation to make corporate governance better, so that $\mathrm{CG}$ has not been able to strengthen the influence or weaken the XBRL variable of voluntary disclosure, volatility, audit quality, firm size, and stock turnover in reducing the level of information asymmetry.

\section{CONCLUSION}

Based on the results of the study, it can be concluded that XBRL has a negative and insignificant effect on information asymmetry. However, in 2010-2014 where before the adoption of XBRL, XBRL had a positive and insignificant effect on information asymmetry. Meanwhile, voluntary disclosure has a positive and significant effect on information asymmetry. However, in 2010-2014 where before the adoption of XBRL, voluntary disclosure had no effect on information asymmetry. Volatility has no effect on information asymmetry. Audit quality has no effect on information asymmetry. Firm Size has no effect on information asymmetry. Stock turnover has no effect on information asymmetry. XBRL, voluntary disclosure, volatility, audit quality, firm size, stock turnover simultaneously, have a significant effect on information asymmetry variables. While the corporate governance variable is not significant as a moderator of the relationship between XBRL, voluntary disclosure, volatility, audit quality, firm size, and stock turnover on information asymmetry.

The limitations of this study are only a few research variables that have a significant effect. The type of company used is only limited to manufacturing companies so that it cannot be generalized to other types of companies such as banking or trading. Based on these limitations, the suggestion for further research is to use other variables that may affect information asymmetry. The use of other types of companies will be considered in further research,

Acknowledgement: None

Conflict of Interest: None

Source of Funding: None 
Fenny Afrida et.al. Determinants of information asymmetries with corporate governance as a moderating variable in manufacturing companies listed on the Indonesia stock exchange.

\section{REFERENCES}

1. Abad, D., Lucas-Pérez, M. E., MinguezVera, A., \& Yagüe, J. (2017). Does gender diversity on corporate boards reduce information asymmetry in equity markets?. BRQ Business Research Quarterly, 20(3), 192-205. DOI: https://doi.org/10.1016/j.brq.2017.04.001

2. Afridah, N., \& Heri Yanto, P. M. P. (2015). Determinan Asimetri Informasi di Seputar Pengumuman Laporan Keuangan Tahunan. Accounting Analysis Journal, 4(2), 1-10.

3. Agus Tri Basuki and Prawoto, Nano. Cetakan Ke 2. 2017. Analisis Regresi Dalam Penelitian. Ekonomi \&Bisnis : Dilengkapi Aplikasi SPSS \& EVIEWS. PT. Rajagrafindo Persada, Depok.

4. Alles, M., \& Piechocki, M. (2012). Will XBRL improve corporate governance? A framework for enhancing governance decision making using interactive data, International Journal of Accounting Information Systems, 13(2), 91-108. DOI:10.1016/j.accinf.2010.09.008

5. Al-Shammari, B., \& Al-Sultan, W. (2010).Corporate governance and voluntary disclosure in Kuwait.International Journal of Disclosure and Governance, 7,262-280. DOI: https://doi.org/10.1057/jdg.2010.3

6. Apriani, N. W. (2018). Pengaruh Asimetri Informasi dan Ukuran Perusahaan pada Income Smoothing dengan GCG sebagai Variabel Moderasi. E-Jurnal Akuntansi Universitas Udayana, 741-746. DOI: https://doi.org/10.24843/EJA.2018.v24.i0 1.p28

7. Arifin, Zaenal. (2005). Teori Keuangan dan Pasar Modal. Yogyakarta: ekonosia.

8. Aryani, M. Z. (2018). Initial Effects of Mandatory XBRL Adoption Across the Indonesia Stock Exchange's Financial Information Environtmen. Jurnal Keuangan dan Perbankan .

9. Ball, Ray, Jayaraman, Sudarshan, Shivakumar, Lakshmanan, (2012). Audited financial reporting and voluntary disclosure as complements: a test of the confirmation hypothesis. J. Account. Econ.53, 136e166.DOI: https://doi.org/10.1016/j.jacceco.2011.11. 005

10. Batchelor, R. A., Alizadeh, A. H., \& Visvikis, I. D. (2014). The relation between bid-ask spreads and price volatility in forward markets. Derivatives Use, Trading \& Regulation, 11(2), 105125.DOI:

https://doi.org/10.1057/9781137554178_8

11. Beekes, W., P. Brown, G. Chin, and Q. Zhang. (2012). The Effects of Corporate Governance, Companies' Disclosure Practices, and Market Transparency: A Cross Country Study. Journal of Business Finance \& Accounting, 43 (1), 263-297. https://doi.org/10.1111/jbfa.12174

12. Biswas, D. (2004). Economics of Information in the Web Economy: Towards a New Theory?.Journal of Business Research, 57 (7), 724-733. DOI: https://doi.org/10.1016/S01482963(02)00355-7.

13. Blankespoor, E., Miller, B. P., \& White, H. D. (2014). Initial Evidence on theMarket Impact of the XBRL Mandate.Review of Accounting Studies. 19(4), 1468-1503. DOI: https://doi.org/10.1007/s11142-013-9273-

14. Brigham, E, F,.\& Houston, Joel.F (2010).Manajemen Keuangan. Edisi kedelapan. Jakarta: Erlangga.

15. Cahyani, N. R., Paminto, A., \& Nadir, M. (2019). Pengaruh gender, board size, firm size dan volatility terhadap asimetri informasi pada sektor industry dan kimia yang terdaftar di bursa efek indonesia. Jurnal Manajemen, 11(1), 4955.

DOI: http://dx.doi.org/10.29264/jmmn.v11i1.46 94

16. Chen, H., \& Li, F. (2013).Analysis the Impact of XBRL in China's Capital Market Using Methods of Empirical Research. Research Journal of Applied Sciences, Engineering and Technology. 5(5), 1521-1527. From https://pdfs.semanticscholar.orgISSN: 2040-7459; e-ISSN: 2040-7467.

17. Chen S., Harris, L., Li, W., \& Wu, D. (2015). How does XBRL affect the cost of equity capital? Evidence from an emerging market, Journal of International 
Fenny Afrida et.al. Determinants of information asymmetries with corporate governance as a moderating variable in manufacturing companies listed on the Indonesia stock exchange.

Accounting Research, American Accounting Association, 14(2), 123145.DOI: https://doi.org/10.2308/jiar51211

18. Christiani, Ingrid dan Yeterina W. Nugrahanti. (2014). "Pengaruh Kualitas Audit Terhadap Manajemen Laba". Jurnal Akuntansi dan Keuangan, Vol.16,No.1, Mei 2014, Hal:52-62. DOI: https://doi.org/10.9744/jak.16.1.52-62

19. Choi, Frederick D. S. Dan Gary K Meek. 2010. International Accounting. Jakarta: Salemba Empat.

20. Chong, Dazhi.,Shi, Hui.,Liuliu.,Ji, Hao \& Yan Gongjun. (2017). The Impact of XBRL on information asymmetry: evidence from loan contracting. Journal if Management Analytics. Vol 4 No.2 Pages 145-158.

DOI: https://doi.org/10.1080/23270012.2017.12 99047

21. Cong, Y., Hao, J., \& Zou, L. (2014).The impact of XBRL on market efficiency, Journal of Information Systems, 28-2, 181-207.DOI: https://doi.org/10.2308/isys-50794

22. Cormier, D., Dufour, D., Luu, P., Teller, P., \& Teller, R. (2018). The relevance ofXBRL voluntary disclosure for stock market valuation: The role of corporate governance. Canadian Journal of Administrative Sciences/Revue Canadienne des Sciences del'Administration, 36(1), 113-127. DOI: https://doi.org/10.1002/cjas.1483

23. Damayanti, D. L., \& Priyadi, M. P. (2016). Pengaruh Karakteristik Perusahaan Pada Luas Pengungkapan Sukarela Dan Implikasinya Terhadap Asimetri Informasi. Jurnal Ilmu dan Riset Akuntansi (JIRA), 5(2).

24. Darmadji, Tjiptono \& Fakhruddin, Hendy M. (2012).Pasar Modal di Indonesia Pendekatan Tanya Jawab. Jakarta: Salemba Empat.

25. Debreceny R., Chandra, A., Cheh, J. J., Guitheus-Amrhein, D., Hannon, N. J., \& Hutchison, P. D.. 2005. Financial Reporting in XBRL on the SEC's EDGAR System: a Critique and Evaluation. Journal of Information Systems, 19 (2),
191-210.

DOI:

https://doi.org/10.2308/jis.2005.19.2.191

26. Debreceny, R., Farewell, S., Piechocki, M., Felden, C., \& Gräning, A. (2010). Does it add up? Early evidence on the data quality of XBRL filings to the SEC. Journal of Accounting and Public Policy, 29(3), 296-306. DOI: https://doi.org/10.1016/j.jaccpubpol.2010. 04.001

27. Easley, D., \& O'hara, M. (2004). Information and the cost of capital. The journal of finance, 59(4), 1553-1583. DOI: $\quad$ https://doi.org/10.1111/j.15406261.2004.00672.x

28. Eng, L. L., \& Mak, Y. T. (2003). Corporate governance and voluntary disclosure. Journal of Accounting and Public Policy, 22(4), 325-345. DOI: https://doi.org/10.1016/S02784254(03)00037-1

29. Erlina.2019. Metode Penelitian Akuntansi dan Format Penulisan Tesis. Medan: USU Press.

30. F, Tzu-Yi.,C.Shih-Hsuan., \& C, KwoLiang. (2017) Does XBRL Adoption Improve Information Asymmetry? Evidence from Taiwan Public Companies. J Glob Econ.4 :172 Pages1-11. DOI: $10.4172 / 2375-4389.1000172$

31. Field, A. (2009). Discovering Statistics Using SPSS. 3rd Edition, Sage Publications Ltd., London. Halim.

32. Fousekis, P. (2020). Sign and Size Asymmetry in the Stock Returns-Implied Volatility Relationship. The Journal of Economic Asymmetries, 21, e00162. DOI:

https://doi.org/10.1016/j.jeca.2020.e00162

33. Francis, J., LaFond, R., Per M. Olsson, \& Schipper, K. (2004). Costs of Equity and Earnings Attributes. The Accounting Review, 79(4), 967-1010. Retrieved June 15, 2021, from http://www.jstor.org/stable/4093083.DOI: https://doi.org/10.2308/accr.2004.79.4.967

34. Frankel, R., and X. Li. 2004.Characteristics of a Firm's Information Environment and the Information Asymmetry between Insiders and Outsiders.Journal of Accounting and Economics, 37 (2), 229-259. DOI: 
Fenny Afrida et.al. Determinants of information asymmetries with corporate governance as a moderating variable in manufacturing companies listed on the Indonesia stock exchange.

https://doi.org/10.1016/j.jacceco.2003.09. 004

35. Fransiska dan Etna (2013). Pengaruh Arus Kas Bebas, Ukuran KAP, Spesialisasi Industri KAP, Audit Tenur dan Independensi Auditor terhadap Manajemen Laba. Journal of Accounting, 2(3)

36. Frino, A., Mollica, V., \& Zhang, S. (2015). Determinants of Bid-Ask Spreads in

37. Time-Series Analysis: A Note. Available at SSRN 2607392 or DOI: https://dx.doi.org/10.2139/ssrn.2607392

38. Geiger, M. A., North, D. S., \& Selby, D. D. (2014). Releasing information inXBRL: Does it improve information asymmetry for early U.S. adopters? Academy of Financial Studies Journal, 18(4), pages 66-84. From http://scholarship.richmond.edu/accountin g-faculty-publications

39. Gerayli, M., Ma'atofa, S., \& Yane Sari, A.M. (2011). "Impact of audit quality on Earnings Management: From Iran". International Research Journal of Finance and Economics, Issue 66, pp. 77-84. From http://www.eurojournals.com/finance.htm

40. Ghozali, Imam. 2013. Aplikasi Analisis Multivariate dengan Program IBM SPSS19, Semarang: Penerbit Universitas Diponegoro.

41. Hajiha, Z. \& N. Sobhani. 2012. Audit Quality and Cost of Equity Capital: Evidence of Iran. International Research Journal of Finance and Economics, 94(1), 159-171. ISSN: 1450-2887.

42. Haß, L. H., Vergauwe, S., \&Zhang, Q. (2014). Corporate Governance and the Information Environment: Evidence from Chinese stock Market. International Review of Financial Analysis, 36 (C), 106-119.

DOI: https://doi.org/10.1016/j.irfa.2014.03.010

43. Harahap, S. N. (2011). Extensible Business Reporting Language: Determinants and Capital Market Implication. Disertasi Fakultas Ekonomi dan Bisnis Universitas Indonesia.

44. Hussainey, K., Mgbame, C. O., \& Chijoke-Mgbame, A. M. (2011). Dividend Policy and Share Price Volatility: UK
Evidence, The Journal of Risk Finance,12(1). DOI: https://doi.org/10.1108/152659411111000 76

45. Indriani, E. W. (2013). Faktor-faktor Yang Mempengaruhi Luas Pengungkapan Sukarela dan Implikasinya Terhadap Asimetri Informasi. Accounting Analysis Journal, AAJ 2 (2), 208-217. DOI: https://doi.org/10.15294/aaj.v2i2.1578

46. Jabeen, M., \& Shah, A. (2011).A review on family ownership and information Asymmetry.African Journal of Business Management, 3 (35), 13550-13558. Available online at http://www.academicjournals.org/AJBM DOI: 10.5897/AJBMX11.025.

47. Japutri, N. J. (2019). Pengaruh Pengadopsian Extensible Business Reporting Language (Xbrl) Terhadap Asimetri Informasi Pada Perusahaan Perbankan Di Bursa Efek Indonesia Periode 2016-2018. Jurnal Akuntansi Kontemporer, 1-9.

48. Jogiyanto, H. (2010). Teori Portofolio dan Analisis Investasi. Edisi Ketujuh. BPFE.Yogyakarta.

49. Khoshbakht, H., \& Mohammadzadeh, H. (2011). Evaluating the relationship between corporate governance and voluntary disclosure in companies listedin Tehran stock exchange. Business and Management Review, 1(9), 23-33. ISSN 2047-0398.

50. Kim, J. W., Lim, J. H., \& No, W. G. (2012). The effect of first wave mandatory XBRL reporting across the financial information environment.Journal of Information Systems, 26(1), 127-153. DOI: https://doi.org/10.2308/isys-10260

51. Kim, J. B., Kim, J. W., \& Lim, H. (2013). Does XBRL adoption constrain managerial opportunism in financial reporting? Evidence from mandated U.S. filers.In CAAA Annual Conference. DOI: https://dx.doi.org/10.2139/ssrn.2201009

52. Komalasari, P. T., \& Baridwan, Z. (2001). Asimetri informasi dan Cost of Equity CapitalThe Indonesian Journal of Accounting Research, 4(1). DOI: http://doi.org/10.33312/ijar.51 
Fenny Afrida et.al. Determinants of information asymmetries with corporate governance as a moderating variable in manufacturing companies listed on the Indonesia stock exchange.

53. Kusumawati, E., Sari, S. P., \& Trisnawati, R. (2013).Pengaruh asimetri informasi dan mekanisme corporate governance terhadap praktik earnings management (kajian perbandingan perusahaan yang terdaftar dalam indeks syariah dan indeks konvensional bursa efek Indonesia). In Seminar Nasional dan Call for paper SANCALL. ISBN: 978-979-636-147-2.

54. Leung, S., \& Horwitz, B. (2004). Director ownership and voluntary segmentdisclosure: Hong Kong evidence. Journal of International Financial Management and Accounting, 15(3), 235260. DOI: https://doi.org/10.1111/j.1467646X.2004.00109.x

55. Leuz, C., \& Verrecchia, R. E.(2000). The Economic Consequences of Increased Disclosure.Journal of Accounting Research, $\quad 91-124 . \quad$ DOI: https://doi.org/10.2307/2672910

56. Li, Xi.,\& Yang, H. I.(2016). Mandatory financial reporting and voluntary disclosure : the effect of mandatory IFRS adoption on management forecasts. The accounting review, 91(3), 933-953. DOI: https://doi.org/10.2308/accr-51296

57. Lin, Y. F., Yeh, Y. M. C., \& Yang, F. M. (2014). Supervisory quality of board and firm performance: a perspective of board meeting attendance. Total Quality Management \& Business Excellence, 25(3-4), 264-279. DOI: https://doi.org/10.1080/14783363.2012.75 6751

58. Liu, C., Luo X. R., Sia, C. L., O’Farrell, G., \& Teo, H. H. (2014). The impact of XBRL adoption in PR China. Decision Support Systems, 59, 242-249. DOI: https://doi.org/10.1016/j.dss.2013.12.003

59. Liu, C., Wang, T., \& Yao, L. J. (2014). XBRL's impact on analyst forecast behavior: An empirical study. Journal of Accounting and Public Policy, 33(1), 6982.

DOI: https://doi.org/10.1016/j.jaccpubpol.2013. 10.004

60. Liu, C., Luo, X. R., \& Wang, F. L. (2017). An empirical investigation on theimpactofXBRL adoption on information asymmetry: Evidence fromEurope. Decision SupportSystems,
93,

42-50.

DOI:

https://doi.org/10.1016/j.dss.2016.09.004

61. Mahardika, S. A., \& Harahap, S. N. (2018). Analisis Pengaruh Adopsi XBRL Terhadap Asimetri Informasi Dengan Corporate Governance Sebagai Pemoderasi. Jurnal Akuntansi dan Keuangan Indonesia, 15(2), 217-236. DOI:

http://dx.doi.org/10.21002/jaki.2018.12

62. Manurung, Haymans Alder. (2013).Teori Investasi: Konsep dan Empiris. PT Alder ManurungPress.

63. Najm-UI-Sehar, B., \& Tufail, S. (2013). Determinants of Voluntary Disclosure in Annual Report: A Case Study of Pakistan. Management and Administrative Sciences Review, 2(2), 181-195. ISSN: 2308-1368.

64. Oktoriza, L. A., \& Surjawati, S. (2019). Pengaruh Komisaris Independen, Komite Audit, Kualitas Audit, Kepemilikan Institusional dan Kepemilikan Manajerial terhadap Asimetri Informasi. Jurnal Dinamika Sosial Budaya, 20(1), 50-56. DOI:

http://dx.doi.org/10.26623/jdsb.v20i1.123 3

65. Patelli, L., \& Prencipe, A. (2007). The relationship between voluntary disclosure and independent directors in the presence of a dominant shareholder. European Accounting Review, 16(1), 5-33. DOI: https://doi.org/10.1080/096381807012658 20

66. Rahman, R. (2016). Pengaruh Kualitas Audit, Tenure Audit Dan Ukuran Perusahaan Terhadap Asimetri Informasi Dengan Komite Audit SebagaiVariabel Pemoderasi (Studi Empiris Pada Perusahaan Manufaktur Periode20132015). FAKULTAS EKONOMI UMY. From:

http://repository.umy.ac.id/handle/123456 789/7940

67. Risdawaty, I. M. E., \& Subowo, S. (2015). Pengaruh struktur modal, ukuran perusahaan, asimetri informasi, dan profitabilitas terhadap kualitas laba. Jurnal Dinamika Akuntansi, 7(2), 109-118. DOI: https://doi.org/10.15294/jda.v7i2.4121

68. Rusmin, R. (2010). Auditor Quality and Earnings 
Fenny Afrida et.al. Determinants of information asymmetries with corporate governance as a moderating variable in manufacturing companies listed on the Indonesia stock exchange.

SingaporeanEvidence.Managerial

Auditing Journal, 25(7), 618-638. DOI: https://doi.org/10.1108/026869010110613 24

69. Santioso, L., \& Angesti, Y. G. (2019). Faktor -Faktor Yang Mempengaruhi Volatilitas Harga Saham Perusahaan Manufaktur. Jurnal Ekonomi, 24(1), 4664. DOI: https://doi.org/10.24912/je.v24i1.450

70. Sari, L. P. (2018). Pengaruh Kualitas Audit, Pengungkapan Sukarela, Audit Tenure, Dan Auditor Spesialis Terhadap Asimetri Informasi Dengan Komite Audit Sebagai Variabel Moderasi (Doctoral dissertation, Universitas Islam Negeri Sultan Syarif Kasim Riau).

71. Sarwono, Jonathan. 2006. Metode Penelitian Kuantitatif dan Kualitatif. Yogyakarta: Graha Ilmu

72. Scott, R. Wiliam.(2015). Financial Accounting Theory Seventh Edition.United States :Pearson. Canada Inc.

73. Septianingrum, V. S. (2020). Pengaruh Penerapan Laporan Keuangan Berbasis Xbrl (Extensible Business Reporting Language) Terhadap Asimetri Informasi (Studi Empiris pada Perusahaan Manufaktur yang Terdaftar di Bursa Efek Indonesia Tahun 2016-2018) (Doctoral dissertation, Universitas Atma Jaya Yogyakarta).

74. Setiawan, J. A., \& DALJONO, D. (2013).Pengaruh Kualitas Audit terhadap Manajemen Laba dan Biaya Modal Ekuitas (Doctoral dissertation, Fakultas Ekonomika dan Bisnis). From: http://eprints.undip.ac.id/42272

75. Shan, Y. G., \& Troshani, I. (2016). The effect of mandatory XBRL and IFRSadoption on audit fees: Evidence from the Shanghai Stock Exchange. International Journal of Managerial Finance, 12(2), 109-135. DOI: https://doi.org/10.1108/JJMF-12-20130139

76. Shaw, K. W. (2003). Corporate Disclosure Quality, Earnings Smoothing, and Earnings' Timeliness.Journal of Business Research, 56 (12), 1043-1050. DOI:
https://doi.org/10.1016/S0148-

2963(01)00328-9

77. Soheilyfar, F., Tamimi, M., Ahmadi, M. R., \& Takhtaei, N. (2014). Disclosurequality and corporate governance: Evidence from Iran. Asian Journal of Finance and Accounting, 6(2), 75-85.

DOI: http://dx.doi.org/10.5296/ajfa.v6i2.6000

78. Sugiyono. (2017). Metode Penelitian Kuantitatif, Kualitatif dan R\&D. Bandung, Indonesia: Alfabeta.

79. Tandiontong, Mathius. (2016). Kualitas Audit dan Pengukurannya, Bandung: Alfabeta.

80. Tangngisalu, J., \& Jumady, E. (2020). Good Corporate Governance Sebagai Pemoderasi: Hubungan Asimetri Informasi Terhadap Manajemen Laba Pada Perusahaan LQ 45. JMBI UNSRAT (Jurnal Ilmiah Manajemen Bisnis dan Inovasi Universitas Sam Ratulangi). 7(1). DOI:

https://doi.org/10.35794/jmbi.v7i1.28373

81. Tessema, Abiot. (2020). "Audit quality, political connections and information asymmetry: evidence from banks in gulf co-operation council countries". International Journal of Management Finance.

https://www.emerald.com/insight/17439132.htm.

82. Tohang, V., \& Lan, M. (2017). The impact of adoption of XBRL on information risk in representative countries of Scandinavian Region. Jurnal Keuangan dan Perbankan, 21(4), 515-526. ISSN: 2443-2687.

83. Umar, Husein, 2003. Metode Riset Akuntansi Terapan. Edisi Pertama. Ghalia Indonesia, Jakarta.

84. Utomo, C. L., \& Juniarti, J. (2020). Pengaruh Penerapan Extensible Business Reporting Language (XBRL) Terhadap Asimetri Informasi Dalam Sektor Pertanian Dan Pertambangan Di Indonesia. Business Accounting Review, 8(1), 75-87.

85. Verrechia, R. E. (2001). Essays on disclosure.Journal of Accountingand Economics, 32(1-3), 97-180. DOI: 
Fenny Afrida et.al. Determinants of information asymmetries with corporate governance as a moderating variable in manufacturing companies listed on the Indonesia stock exchange.

https://doi.org/10.1016/S0165-

4101(01)00025-8

86. Wang, T., Wen, C. Y., \& Seng, J. L. (2014).The association between the mandatory adoption of XBRL and the performance of listed state-owned enterprises and non-state-owned enterprises in China. Information \& Management, 51(3), 336-346. DOI: https://doi.org/10.1016/j.im.2014.02.006

87. Weber, R. A. G. (2003). XML, XBRL, and the Future of Business and Business Reporting. In D. S. J. Roohani (Ed.), Trust and Data Assurances in Capital Markets: The Role of Technology Solutions (1 ed., pp. 3 - 6). Bryant College. From: https://espace.library.uq.edu.au/view/UQ: 69325

88. Welker, M. 2010. Disclosure policy, Information asymmetry and Liquidity in Equity Markets. Contemporary Accounting Research, 11 (2), 801 - 827. DOI: https://doi.org/10.1111/j.19113846.1995.tb00467.x

89. Widiarti, T. (2018). Faktor-faktor yang mempengaruhi volatilitas harga saham pada perusahaan yang terdaftar Di indeks lq 45 (Doctoral dissertation, STIE PERBANAS SURABAYA). From: https://kc.umn.ac.id/id/eprint/6474
90. Yoga. (2010). Hubungan Teori Signalling Dengan Underpricing Saham Pada Penawaran Perdana (Ipo) Di Bursa Efek Jakarta.Eksplorasi Vol.5, no.1, edisi maret 2010.

91. Yoon, H., Zo, H., \& Ciganek, A. P. (2011). Does XBRL adoption reduce Information asymmetry? Journal of Business Research, 64(2), 157-163. DOI: https://doi.org/10.1016/j.jbusres.2010.01.0 08

92. Zamroni, M., \& Aryani, Y. A. (2018). Initial effects of mandatory XBRL adoption across the Indonesia stock exchange's financial information environment. Jurnal Keuangan dan Perbankan, 22(2), 181-197. DOI: https://doi.org/10.26905/jkdp.v22i2.2092

How to cite this article: Fenny Afrida, Idhar Yahya, Chandra Situmeang. Determinants of information asymmetries with corporate governance as a moderating variable in manufacturing companies listed on the Indonesia stock exchange. International Journal of Research and Review. 2022; 9(1): 251-268. DOI: https://doi.org/10.52403/ijrr. 20220131 